EDWARD GUZIAKIEWICZ

Mielec

eduardus@wp.pl

\title{
Rajski owoc i podstawy biblijnej moralności
}

Oparty na konfiguracji pojęć „duch”, „dusza” i „ciało” trójdzielny model antropologiczny rzutuje nie tylko na wyobrażenia eschatologiczne Starego i Nowego Testamentu ${ }^{1}$. Tworzy on podwaliny nauki o trojakiej pożądliwości i można zauważyć, że wyrastająz niego jak z pnia gałęzie biblijnej moralności. Rzuci się to w oczy, jeśli zestawi się teksty biblijne według klucza trynitarnego. Biorąc pod uwagę Stary Testament, wypada odwołać się w tym kontekście do biblijnego opisu upadku pierwszej pary ludzkiej z Rdz 3, 1-24 oraz do nakazu miłości Boga z Pwt 6, 4-5, zaś w przypadku Nowego Testamentu - do zwięzłego wywodu o trojakiej pożądliwości z 1 J 2, 16-17 oraz do opisów kuszenia Jezusa na pustyni z Ewangelii synoptycznych.

\section{1. „Będziesz miłował Pana, Boga twego...”}

Starotestamentowe przykazanie miłości Boga brzmi jasno i w sposób nie budzący wątpliwości. „Słuchaj, Izraelu, Pan jest naszym Bogiem - Panem

\footnotetext{
${ }^{1}$ Autor nawiązuje tu do swoich wcześniejszych opracowań z tego zakresu: E. Guziakiewicz, Zmartwychwstanie ku doskonałej jedności ciała, duszy i ducha, „Ateneum Kapłańskie” 140 (2003) z. 3, s. 416-428; tenże, Wokót zmartwychwstania umarlych. W poszukiwaniu klucza antropologicznego, „Ateneum Kapłańskie” 151 (2008) z. 2, s. 339-348; tenże, Zmartwychwstanie umarlych. Klucz antropologiczny, Sandomierz 2011.
} 
jedynym. Będziesz miłował Pana, Boga twojego - uczy Księga Powtórzonego Prawa - z całego swego serca, z całej duszy swojej, ze wszystkich swych sił" $(6,4-5)$. Tekst ten stanowi początek modlitwy Szema Izrael odmawianej już w czasach Drugiej Świątyni. Szema jest obecnie jedną z dwóch najważniejszych modlitw Izraelity i obejmuje następujące fragmenty: Pwt 6, 4-9; Pwt 11, 13-21; Lb 15, 37-41. Przywoływane przykazanie miłości Boga było więc i jest dobrze znane wyznawcom judaizmu. Człowiek ma miłować Boga całym jestestwem, a więc duchem, duszą i ciałem. Trudno nie dostrzegać ścisłej korelacji tego trójczłonowego zestawienia z trójdzielnym modelem antropologicznym, zważywszy, że serce w myśli starotestamentowej jest synonimem jaźni i umysłu człowieka ${ }^{2}$, a siły odnoszą się do ciała ludzkiego, które wyraża duchową aktywność osoby ludzkiej.

Tekst ten, kilkakrotnie przywoływany w Nowym Testamencie, odbiega od pierwotnej wersji z Pięcioksięgu i jest cytowany niedokładnie. Jezus odpowiada na pytanie uczonego w Piśmie o to, co jest najważniejszym przykazaniem (por. Mt 22, 37; Mk 12, 30; Łk 10, 27). Jednak w Jego ustach pojawia się dodatkowy element: „całym swoim umysłem”, którego nie ma w Pwt 6, 5. W Ewangelii według św. Mateusza zastępuje on zwrot „ze wszystkich sił”, w Ewangelii według św. Marka i św. Łukasza stanowi zaś dopełnienie pierwotnego wyliczenia, z tym że u św. Marka pojawia się na trzecim miejscu, a u św. Łukasza na czwartym. Skąd się wzięły te różnice? Najbardziej prawdopodobne wydaje się wyjaśnienie, że w procesie redakcji Ewangelii synoptycznych korzystano m.in. z manuskryptu greckiego, w który wkradł się błąd. Mogły też w grę wchodzić inne przyczyny. „Wprowadzenie zmian do tekstu Biblii w celu dostosowania go do zamierzonej przez tłumacza interpretacji - pisze Andrzej Kowalczyk - było w środowisku żydowskich uczonych w Piśmie znane i akceptowane”3.

${ }^{2}$ J. de Fraine, A. Vanhoye, Serce, [w:] Stownik teologii biblijnej, red. X. Léon-Dufour, tłum. K. Romaniuk, Pallottinum, Poznań-Warszawa 1985, s. 871-873. Współczesne znaczenie pojęcia „serce” jest inne niż w kulturze semickiej, a przeciwstawia się je pojęciu „rozumu” - zob. np. M. Jarymowicz, Racje serca i racje rozumu - w poszukiwaniu sensu idei powszechnie znanej, [w:] Nowe idee w psychologii, red. nauk. J. Kozielecki, Gdańsk 2009, s. 183-215.

${ }^{3}$ A. Kowalczyk, Motywy zmian w Mateuszowych cytatach Starego Testamentu niezgodnych $z$ tekstem masoreckim i Septuaginta, „Studia Gdańskie” 8 (1992), s. 5. Wspomniany 


\section{Drzewo poznania dobra i zła}

Wypada wrócić do biblijnego opowiadania o upadku. Według relacji Księgi Rodzaju Bóg, zasadziwszy ogród, sprawił, że w jego środku wyrosły drzewo życia oraz drzewo poznania dobra i zła (por. Rdz 2, 8). Pierwsi ludzie mogli jeść owoce z wszystkich drzew ogrodu, łącznie z owocami z drzewa życia, jednak owoców z drzewa poznania nie wolno im było spożywać (por. Rdz 2, 16-17).

W biblijnym opowiadaniu o grzechu z Rdz 3, 1-21 szatan pojawia się w ogrodzie Eden w postaci przebiegłego węża (por. Ap 12, 9. 14-15; 20, 2). Podstępnie nakłania pierwszych rodziców do buntu. Pod wpływem namowy upadłego anioła niewiasta sięga po zakazany owoc. Zerwanie i spożycie tego owocu zgodnie z obietnicą złego ducha ma pozwolić człowiekowi wyrwać się z ograniczeń nałożonych przez Stwórcę i bez skrępowania zanurzyć w morzu przyjemności, posiadania i władzy. Jest to oczywiście niebezpieczne złudzenie. Człowiek jako byt przygodny nie jest w stanie zająć miejsca Stwórcy ani też zamienić swego życia w pasmo nieustannych rozkoszy. Tylko Bóg jest bowiem absolutnym dobrem i źródłem szczęścia człowieka oraz celem ostatecznym istoty ludzkiej ${ }^{4}$. Zerwanie $\mathrm{z}$ Nim jest równoznaczne $\mathrm{z}$ wyborem śmierci.

Biblia nie wskazała nazwy gatunku owocu z zakazanego drzewa, co pozostawiało miejsce na spekulacje i domysły. Tradycja hebrajska widziała w nim owoc winnego krzewu lub figowca, względnie drzewa cytrynowego, a nawet łodygi pszenicy. Powoływano się również na owoc granatu. Motywy biblijnego opowiadania o stworzeniu i upadku znaczyły się w kulturze europejskiej na różne sposoby. Średniowieczni i renesansowi artyści na swych obrazach umieszczali rajską jabłoń. Zakazany owoc przyjmował więc postać jabłka. Prawdopodobną przyczyną takiego stanu rzeczy było to, że łacińskie słowo malum oznaczało równocześnie „zło” i „jabłko”. Na marginesie można zaznaczyć, że męską grdykę zaczęto nazywać jabłkiem Adama, bowiem zgodnie z popularnymi wyobrażeniami

autor jest zdania, że modyfikacja tekstu Mt 22, 37 została dokonana pod wpływem Joz 22, 5 - por. tamże, s. 14 .

${ }^{4}$ Por. Jan Paweł II, enc. Veritatis splendor, 9-12. 
pierwszemu mężczyźnie miał utkwić w gardle kawałek zakazanego owocu. To anatomiczne określenie utrzymało się w wielu językach europejskich (la pomme d'Adam, Adam's apple, Adamsapfel, adamsappel, Adamovo jabłko, adamsceble, úll Adam, Aadama õun i inne).

Od nazbyt swobodnych naturalistycznych interpretacji opowiadań Księgi Rodzaju daleko ważniejsze są jednak interpretacje filologiczne i teologiczne, odwołujące się do zastosowanego w tekście gatunku literackiego (mit lub narracja realistyczno-symboliczna) i do dobrze pojętego kontekstu biblijnego. Drzewo poznania dobra i zła symbolizuje porządek Boży, dlatego objaśnienia powinny odnosić się do tego porządku, a nie do świata ziemskiej flory. Istotne jest to, co Biblia uczy o tym owocu. Z punktu widzenia prowadzonych tu analiz znaczenie zaś ma to, jak kuszonej kobiecie, matce wszystkich żyjących, jawią się owe owoce z zakazanego drzewa po tym, co słyszy od diabła.

Brzmią więc w Księdze Rodzaju znamienne słowa: „Wtedy niewiasta spostrzegła,

[1] że drzewo to ma owoce dobre do jedzenia,

[2] że jest ono rozkoszą dla oczu

[3] i że owoce tego drzewa nadają się do zdobycia wiedzy.

Zerwała zatem z niego owoc, skosztowała i dała swemu mężowi” $(\mathrm{Rdz} 3,6)$.

Wzmiankowany owoc z drzewa poznania jest w cytowanym tekście biblijnym scharakteryzowany przy pomocy trzech lapidarnych konstatacji zdających się składać na metaforyczny zabieg językowy o nikłym znaczeniu teologicznym. Jednak przy głębszym wczytaniu się w to opowiadanie widać, że charakterystyka owego owocu nie jest wcale przypadkowa, a biblijny narrator odwołuje się w niej do solidnego i dobrze mu znanego fundamentu antropologicznego.

Wymowa przytoczonego fragmentu zdecydowanie się pogłębi, jeśli wzorem niektórych Ojców Kościoła zestawi się jego krótką treść z objaśnieniem trojakiej natury pożądliwości zawartym w 1 Liście św. Jana. W egzegezie biblijnej ostatnich dziesięcioleci zabrakło tradycji badania omawianego wersetu pod tym właśnie kątem. „Wszystko bowiem, co jest na świecie - pisze jego autor natchniony - a więc: pożądliwość ciała, pożądliwość oczu i pycha tego żywota, nie pochodzi od Ojca, lecz od świata” 
(1 J 2, 16 $)^{5}$. Janowa struktura pożądliwości odpowiada - co jest najzupełniej zrozumiałe - przywoływanej strukturze bytu ludzkiego. Biblijna pożądliwość ciała odnosi się do cielesności człowieka, a więc do tego, co w akcie stwórczym zostało wzięte „z prochu ziemi” (w opisie Księgi Rodzaju: „drzewo to ma owoce dobre do jedzenia”); pożądliwość oczu - do ludzkiej duszy (,jest ono rozkoszą dla oczu”), zaś pycha tego żywota - do ludzkiego ducha („owoce tego drzewa nadają się do zdobycia wiedzy”).

\begin{tabular}{|l|l|l|}
\hline duch & pycha tego żywota & „owoce tego drzewa nadają się do zdobycia wiedzy” \\
\hline dusza & pożądliwość oczu & „jest ono rozkoszą dla oczu” \\
\hline ciało & pożądliwość ciała & „drzewo to ma owoce dobre do jedzenia” \\
\hline
\end{tabular}

Zrywając zakazany owoc z drzewa poznania dobra i zła, pierwsza para ludzka, ze względu na swe niezwykłe usytuowanie, naruszyła pierwotną harmonię stworzenia i w konsekwencji poddała siebie oraz swe potomstwo prawu przemijania (grzech pierworodny). Utraciła rajską niewinność, z którą wiązała się nieznajomość zła ${ }^{6}$. Zniszczeniu uległa wpisana w ludzką naturę pierwotna matryca moralna, dzięki której człowiek, ukierunkowany na mocy aktu stwórczego na swego Stwórcę, pozostawał z Nim w głębokiej przyjaźni. W wojnie upadłych aniołów z Bogiem ${ }^{7}$ te ostatnie odniosły zwycięstwo, wyrywając pierwotną parę ludzką spod kurateli Stwórcy i poddając ją sobie, co zaowocowało wypędzeniem $\mathrm{z}$ ogrodu Eden będącego paradygmatem niezakłóconej więzi między Bogiem a ludźmi oraz między ludźmi a przyrodą ${ }^{8}$. W strukturę bytową pierwszego człowieka wkradły się groź-

${ }^{5}$ Stworzony przez Boga „człowiek był nieskazitelny i uporządkowany w swoim bycie, ponieważ był wolny od potrójnej pożądliwości (por. $1 \mathrm{~J} 2,16$ ), która poddaje go przyjemnościom zmysłowym, pożądaniu dóbr ziemskich i afirmacji siebie wbrew nakazom rozumu" (Katechizm Kościoła katolickiego, 377).

${ }^{6}$ Różne sposoby rozumienia znaczenia zerwania owocu z drzewa poznania dobra i zła prezentuje i krytycznie omawia: D. Dziadosz, Teologiczna struktura relacji o ogrodzie Eden (Rdz 2, 4b-25), „Studia Gdańskie” 27 (2010), s. 23-31.

${ }^{7}$ Por. Katechizm Kościoła katolickiego, 391-393.

${ }^{8}$ Fenomen upadku jest interpretowany na różne sposoby, stanowiąc intrygujący punkt odniesienia dla współczesnych badań psychologicznych i kulturowych. Na temat 
ne pęknięcia, w rezultacie czego stracił on posiadane przywileje, przede wszystkim zaś nieśmiertelność. A ponieważ został umieszczony przez Boga w centrum dzieła stworzenia, będąc niejako jego kamieniem węgielnym, skutki jego grzechu stały się odczuwalne w całym kosmosie. Całe stworzenie - jak uczą księgi biblijne - uczestniczyło w jego klęsce. To stworzenie będzie później zgodnie ze słowami św. Pawła z Listu do Rzymian oczekiwać w bólach objawienia się synów Bożych (por. Rz 8, 18-22).

Zmiana opcji fundamentalnej polegająca na odwróceniu się od jedynego Boga i zwróceniu się ku bożkom ${ }^{9}$ wpisuje się trwale w dzieje narodu wybranego, a prorocy wskazują na nią jako na przyczynę niepowodzeń politycznych Izraela. Pierwotny porządek w świecie, w który wtargnął zły duch (por. Syr 25, 24) spychający pierwszą parę ludzką w sferę grzechu i śmierci (por. Mdr 2, 23-24), zgodnie z przesłaniem ksiąg świętych Izraela może przywrócić dopiero Mesjasz. Oczekiwanie Izraela na pełne zwycięstwo nad mocami zła jest więc związane z nadzieją Jego nadejścia.

Sumując powyższe uwagi, wypada stwierdzić, że przykazanie miłości Boga, tak jak ono jest ujęte w Pwt 6, 5, pozostaje ściśle związane z trójdzielną strukturą bytu ludzkiego. Ponadto ukazuje ono „receptę” na ontyczne pęknięcie wywołane egoizmem pierwszych rodziców. Droga powrotu do ogrodu Eden może prowadzić tylko przez miłość, która w Nowym Testamencie jest wyraźnie powiązana z naturą Boga i udzielaniem się Ducha Świętego.

\section{Triada moralna (rady ewangeliczne)}

Wypada zaznaczyć, że związane z życiem zakonnym rady ewangeliczne: czystość, ubóstwo i posłuszeństwo odpowiadają tej charakterystycznej

refleksji nad symboliką zła (w tym dramatu kuszenia) zob. P. Ricoeur, Symbolika zła, przeł. S. Cichowicz, M. Ochab, Warszawa 1986.

9 „Bałwochwalstwo nie dotyczy tylko fałszywych kultów pogańskich. Pozostaje stałą pokusą wiary. Polega na ubóstwianiu tego, co nie jest Bogiem. Ma ono miejsce wtedy, gdy człowiek czci i wielbi stworzenie zamiast Boga, bez względu na to, czy chodzi o innych bogów czy o demony (na przykład satanizm), o władzę, przyjemność, rasę, przodków, państwo, pieniądze itd." (Katechizm Kościoła katolickiego, 2113). 
trójdzielnej strukturze i do niej się odnoszą. Są one niejako ascetyczną reakcją na trzy wskazane przez św. Jana zasadnicze słabości (trojaką pożądliwość będącą skutkiem zerwania pierwotnego przymierza z Bogiem), którym poddany jest człowiek żyjący w porządku grzechu ${ }^{10}$. Posłuszeństwo (podporządkowanie się przełożonym) jest odpowiedzią na pokusę władzy, dobrowolne ubóstwo, czyli rezygnacja z osobistego majątku (por. Mt 19, 21; Mk 10, 21; Łk 18, 22; por. Dz 2, 45) - na pokusę nieograniczonego posiadania dóbr materialnych, czystość (celibat) - na pokusę uczynienia z przyjemności zmysłowych (doznań erotycznych) celu życia.

Życie w czystości, ubóstwie i posłuszeństwie jest w myśli chrześcijańskiej znakiem dóbr eschatologicznych i na nie wskazuje jako na swą najgłębszą rację. Stanowi ono szczególną antycypację przyszłego zmartwychwstania, o czym w rozmowie z saduceuszami przypomina Jezus uczący o bezżenności zmartwychwstałych mających być „jak aniołowie w niebie” (Mt 22, 30; Mk 12, 24-25; Łk 20, 34-36) ${ }^{11}$. Temat bezżenności (dziewictwa) w podobnym tonie podejmuje także św. Paweł w 1 Kor 7, 5-40 ${ }^{12}$.

Postulaty zawarte w radach ewangelicznych dotyczą na swój sposób wszystkich chrześcijan, co widać w Nowym Testamencie. Idea wspólnoty dóbr jest zarysowana w pierwszym summarium z Dziejów Apostolskich (2, 42-47). Poza tym św. Paweł uczy: „Mówię, bracia, czas jest krótki. Trzeba więc, aby ci, którzy mają żony, tak żyli, jakby byli nieżonaci, a ci, którzy płaczą, tak jakby nie płakali, ci zaś, co się radują, tak jakby się nie radowali; ci, którzy nabywają, jak gdyby nie posiadali; ci, którzy używają tego świata, tak jakby z niego nie korzystali" (1 Kor 7, 29-31).

10 „Matka-Kościół cieszy się, że w łonie jego znajdują się liczni mężczyźni i niewiasty, którzy dokładniej naśladują wyniszczenie Zbawiciela i wyraźniej je ukazują, przyjmując ubóstwo w wolności synów Bożych i wyrzekając się własnej woli: poddają się oni mianowicie człowiekowi ze względu na Boga w sprawie doskonałości ponad miarę przykazania, aby się w sposób pełniejszy upodobnić do posłusznego Chrystusa” (Katechizm Kościoła katolickiego, 2103).

${ }^{11}$ Jan Paweł II, Mężczyzną i niewiastą stworzył ich. Odkupienie ciała a sakramentalność małżeństwa, Roma 1986, s. 285-316.

12 Tamże, s. 316-334. 
Omawiana triada moralna zaznacza się w opisach kuszenia Jezusa na pustyni (por. Mt 4,1-11; Łk 4,1-13) ${ }^{13}$. Szatan odwołuje się do tych samych pokus, co w opowiadaniu o upadku pierwszych ludzi z Księgi Rodzaju, tyle że są tu one lepiej wyeksponowane. W przeciwieństwie do pierwszych rodziców w raju Jezus umocniony przez Ducha (por. Mt 3, 16-17; $4,1)$ odpiera zakusy diabła. Walka między Nim a kusicielem rozgrywa się w trzech odsłonach odpowiadających trzem kolejnym pożądliwościom, zaś Jezus ze wszystkich starć wychodzi zwycięsko, nie paktując z ojcem kłamstwa. Odpowiedzi, których udziela diabłu, pochodzą z Pwt 6-8.

Reminiscencją omawianego biblijnego trójpodziału jest przywoływana przez ojców Kościoła moralna parcelacja wierzących na „duchowych”

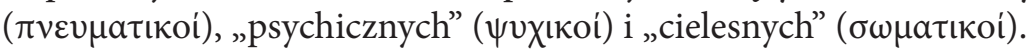

Jej podstawy można znaleźć w Nowym Testamencie w Listach św. Pawła, w których takie rozróżnienie zaczyna się zaznaczać. „A ja nie mogłem, bracia, przemawiać do was jako do ludzi duchowych - pisze Apostoł Narodów - lecz jako do cielesnych, jako do niemowląt w Chrystusie. Mleko wam dałem, a nie pokarm stały, boście byli niemocni; zresztą i nadal nie jesteście mocni. Ciągle przecież jeszcze jesteście cieleśni. Jeżeli bowiem jest między wami zawiść i niezgoda, to czyż nie jesteście cieleśni i nie postępujecie tylko po ludzku?" (1 Kor 3, 1-3; por. 2 Kor 2, 14-4, 6; 5, 16; Ga $5,16-17 ; 6,1)$. O różnicy między cielesnym i duchowym Izraelem pisze św. Paweł w Liście do Rzymian (9, 6-8; 11, 7-8).

Tak ujęty patrystyczny trójpodział nie odnosi się jednak do natury człowieka, ale ma charakter typologii społeczno-moralnej.

${ }^{13}$ A. Feuillet, Tajemnica kuszenia Jezusa, „Communio” 7 (1992), s. 50-65; A. Burakowska, Kuszenie Jezusa, „Communio” 1 (2006), s. 80-85. 


\section{Abstrakt}

\section{Rajski owoc i podstawy biblijnej moralności}

Autor ukazuje związki między trójdzielnym modelem antropologicznym a trójdzielnym schematem biblijnej moralności. Interpretuje w tym świetle opis owocu z drzewa poznania dobra i zła. Znaczącym odniesieniem jest biblijna nauka o trojakiej pożądliwości, której czytelnym odbiciem są rady ewangeliczne.

\section{Słowa kluczowe}

Biblia, Bóg, eschatologia, antropologia, moralność, upadek, drzewo poznania, jabłko Adama, rady ewangeliczne

\section{Abstract}

\section{Paradise fruit and basics of biblical morality}

The author shows relations between triple anthropological model and triple scheme of biblical morality. He interprets in this area, description of a fruit from the Tree of Knowledge. Significant reference is biblical study about triform concupiscence, which has legible impress in the evangelical counsels.

\section{Keywords}

Bible, God, eschatology, anthropology, morality, sin, tree of knowledge, Adam's apple, the evangelical counsels

\section{Bibliografia}

Burakowska A., Kuszenie Jezusa, „Communio” 1 (2006), s. 80-85.

De Fraine J., Vanhoye A., Serce, [w:] Słownik teologii biblijnej, red. X. Léon-Dufour, tłum. K. Romaniuk, Pallottinum, Poznań-Warszawa 1985, s. 871-873. 
Dziadosz D., Teologiczna struktura relacji o ogrodzie Eden (Rdz 2, 4b-25), „Studia Gdańskie” 27 (2010), s. 23-31.

Feuillet A., Tajemnica kuszenia Jezusa, „Communio” 7 (1992), s. 50-65.

Guziakiewicz E., Wokół zmartwychwstania umarłych. W poszukiwaniu klucza antropologicznego, „Ateneum Kapłańskie” 151 (2008) z. 2, s. 339-348.

Guziakiewicz E., Zmartwychwstanie ku doskonałej jedności ciała, duszy i ducha, „Ateneum Kapłańskie” 140 (2003) z. 3, s. 416-428.

Guziakiewicz E., Zmartwychwstanie umarlych. Klucz antropologiczny, Sandomierz 2011.

Jan Paweł II, Mężczyzną i niewiastą stworzył ich. Odkupienie ciała a sakramentalność małżeństwa, Roma 1986.

Jan Paweł II, enc. Veritatis splendor (6 sierpnia 1993): „Acta Apostolicae Sedis” 85 (1993), 1133-1228.

Jarymowicz M., Racje serca i racje rozumu - w poszukiwaniu sensu idei powszechnie znanej, [w:] Nowe idee w psychologii, red. nauk. J. Kozielecki, Gdańskie Wydawnictwo Psychologiczne, Gdańsk 2009, s. 183-215.

Katechizm Kościoła katolickiego, Poznań 2002.

Kowalczyk A., Motywy zmian w Mateuszowych cytatach Starego Testamentu niezgodnych z tekstem masoreckim i Septuagintą, „Studia Gdańskie” 8 (1992).

Ricoeur P., Symbolika zła, przeł. S. Cichowicz, M. Ochab, Warszawa 1986. 